\section{The Effects of Chavez's Populism on Today's Venezuela}

\section{Italia Messina}

Sophomore, Global Studies \& Political Science

In the beginning of his presidency, Hugo Chavez was a hero to many Venezuelan citizens. He was elected in 1998 on the basis of "giving power to the people" (Carrillo 2016) and eradicating corruption from Venezuela's political system. He allowed the people to share in the country's wealth and created enviable social welfare programs to lift people out of poverty. Chavez made this feasible by rigging the economy to be entirely dependent on the country's oil reserves. Throughout his presidency, Chavez spent billions on social welfare programs to keep poor Venezuelans happy and ultimately ran a severe budget deficit (Ellis 2017). Corrupt Venezuelan president Nicolas Maduro succeeded Chavez in 2013 and has been unable to manage the tanking economy since the rapid decline of oil prices in 2014. Venezuela's sunken economy and high level of government corruption has caused massive security issues regarding health care, education, and employment resulting in high levels of violence and instability. In order to avoid further exacerbation of the current Venezuelan crisis, certain actions such as economic sanctions, international involvement, and foreign aid must be considered in alleviating the plight of Venezuelan citizens.

Both Chavez and Maduro may be held responsible for the current crises in
Venezuela. Chavez's reliance on high oil followed by Maduro's corrupt political practices have proven to be deep causes of the country's problems. Since his election, Maduro has forcibly removed any Supreme Court justices openly opposing him and created a new Supreme Court comprised of loyal cronies. In 2017, he instituted a new National Constituent Assembly with the power to rewrite Venezuela's constitution and overpower the National Assembly (Ellis 2017). Maduro is currently the single, ultimate authority of Venezuela.

Venezuela's current climate has fostered great hostility among citizens who have been plunged into poverty. Eighty percent of Venezuelans have voted for the removal of Maduro from office and urged replacement of someone who will provide economic and societal stability (Ellis 2017). As Maduro continues to consolidate power in the hope of "clearing the decks for a presidential run in 2018" (Faiola and Krygier 2017), and protests grow increasingly dangerous in the streets, a rising number of Venezuelans will continue to suffer from lack of basic needs and lack of universal human rights.

The Venezuelan crisis originated as domestic security issue contained within the country but has spiraled into a global crisis due to the number of refugees flooding into neighboring countries. The United Nations reports that about 2.3 million Venezuelans have fled their country over the past two years, many by selling their belongings and boarding public transportation (Tharoor 2018). The mass exodus of Venezuelans into the countries of Colombia, Brazil, Ecuador, Peru, and Chile has had adverse effects on the entire region and has placed 
immeasurable stress on health, education, and financial services. According to the New York Times, mass vilence is a daily occurrence at territorial borders, and xenophobic attitudes toward Venezuelans have resulted in lynchings by citizens of several host nations (Castaneda 2018). Given that Venezuela's crisis has begun to cross borders, it may soon be time for the international community to intervene with the federal government. One could also argue that the behavior of the Venezuelan government is pushing citizens out of their homes. Maduro and his cronies and deliberately instilling fear inside the civilian population and causing physical and psychological destruction ino rder to achieve a political agenda. These tactics may also be recognized as terrorism. Hundreds of Venezuelan civilians, activists, and former government employees have reported on the Maduro regime's use of crimes against humanity including rape, murder, torture, and illegal detention, "all in an attempt to make individuals regret ever having dared to express their inalienable right to speech, to protest, to clamor for a better life" (Scharifker 2018). This state-sponsored violence has evolved into a form of hard power that Maduro uses to support his selfproclaimed legitimacy.

Multiple aspects of human welfare play into Venezuela's plight, including a severe health crisis and drastic economic insecurity. The healthcare system is in shambles, and hospitals lack basic technology, medicine, sanitary supplies, and electricity. Unless patients provide their own, doctors have no choice but to reuse items such as surgical gloves and respiratory masks worn by other patients (Watts 2016). Many Venezuelans purchase medical supplies on the black market. These supplies are typically smuggled into the country from Brazil or Colombia and sold for about three times their actual worth (Raphelson 2018). The absence of pharmaceutical supplies is yet another source of anger among civilians that has led to additional protests. The government has been blaming, detaining, and questioning doctors and pharmacy chains for the shortage, "while its currency exchange restrictions and price controls interfere with the ability of pharmaceutical companies to sell them" (Lohman 2015). Along with an extreme deficit of medical supplies, Venezuelan hospitals are barely functioning and have transformed into wastelands. Staff and patients report having received death threats and having been mugged inside hospitals. Preventable diseases such as malaria, diphtheria, and marasmus have risen sharply, and "U.N. officials claim that some 1.3 million Venezuelans who fled the country were 'suffering from malnourishment"' (Tharoor 2018). Aljazeera reports that "malaria cases have jumped by an estimated 69 percent last year" (Aljazeera 2018), and that the infant mortality rate is so high that women are seeking dangerous and illegal abortions (Marillier and Squires 2018). As a result of these conditions, it is not surprising that thousands of doctors have fled Venezuela in search of more promising opportunities (Watts 2016).

The health crisis and extreme economic insecurity in Venezuela have caused crime and homicide rates to surge. According to the Observatory of Venezuelan 
Violence, 28,479 violent deaths took place in 2016, meaning that there were approximately 92 deaths per 100,000 residents. Venezuela's homicide rate is now the second-highest in the world after El Salvador (Wyss 2017). Many Venezuelans have turned to violence as a method of obtaining food by robbing restaurants and grocery stores to feed themselves or their families (Nugent 2018). Moreover, organized crime has permeated the lives of most Venezuelan citizens and such state institutions as the National Guard and National Assembly. Many Venezuelan people have fallen victim to drug and fuel trafficking through the "Cartel of the Suns," named after the golden stars worn on the Bolivarian National Guard's epaulets. The National Guard, responsible for internal security, frontiers, ports, and airports, controls access to the country and is often bribed by drug traffickers to allow shipments of cocaine to pass through the borders (Venezuela Investigative Unit 2018). A combination of these issues contributes to Venezuela's ranking as the "least-safe country for two years straight" (Shugerman 2018) by the Gallup report on global law and order.

Given that a significant amount of Venezuela's human security issues stem from economic problems, focusing in on the economy would be a sensible starting point. However, the economy is so shattered beyond normality that the usual solutions for inflation would not have any real effects for decades to come. Higher interest rates are useful only when spending is especially high, and Venezuelans have not necessarily been spending exorbitant amounts of money.
A tight fiscal policy in which income taxes are raised and government spending is lowered would be insufficient, as well, due to the fact that many Venezuelans receive little to no income in their current economic climate. A possible avenue for resolving this crisis is for the international community to put stronger sanctions on oil purchases and freeze the bank accounts of Venezuelan leaders. Although they would further destroy any remaining wealth of the Venezuelan people, oil sanctions would be harsh but effective. At a "high cost and with multiple complications" (Castaneda 2018), the Venezuelan regime would be forced to find other buyers, thus stripping themselves of much of their earnings and wealth. In order to rebuild Venezuela's economy for longterm function, the deep causes of the crisis must be reversed. Venezuela must explore other options, rather than solely rely on oil reserves, for supporting their economy.

In addition to economic reforms, there has been debate over the effects of a possible military coup against the Venezuelan government. During the summer of 2018, senior-level officers from the Venezuelan army approached the Trump Administration with plans of a military coup d'état against Maduro and "requested telecommunications support for that purpose" (Castaneda 2018). The Trump administration declined, and the Venezuelan officers carried out a botched drone attack on Maduro during his speech on August 4th, 2018. Maduro arrested and presumably tortured the army officers and proceeded to accuse Juan Manuel Santos, the former president of Colombia, of plotting the conspiracy (Castaneda 2018). Fernando 
Alban, a city counselor of Caracas who openly criticized Maduro, was recently reported dead after an alleged suicide. Alban was a suspect of the 2018 botched drone attack, and many critics have cited his death as "...a massive crackdown on opposition groups and human rights activists" (Berlinger and Gafas 2018) by the Maduro regime. The majority of Venezuelans are opposed to external intervention, especially by the United States, as they believe that it would partially validate "Maduro's loudly proclaimed imperialist conspiracies" (O'Neil 2018). In addition to increasing both Maduro's and Venezuelan citizens' fears of U.S. imperialism, external intervention would make the intervening country responsible for repairing Venezuela's deteriorated institutions. Rebuilding the nation's electricity grids, sewage systems, hospitals, schools, and other social structures will be an arduous process and "any failure would be pinned on the U.S." (O'Neil 2018). The prospect of external intervention also raises the question of state sovereignty. The concept of state sovereignty encourages the international community to respect the prerogatives of other states, even if these pregatives include refusing to accept donations and aid packages from other nations (Raphelson 2018), ignoring the fact that twenty-five percent of its children are malnourished (Watts 2016), and denying its citizens most basic needs.

Another option for removing Maduro from office is collective action by the international community. The ICC received a referral from Argentina, Canada, Colombia, Chile, Paraguay, and Peru regarding the crimes against humanity committed by the Venezuelan government (International Criminal Court 2018). The preliminary examination is following its normal course and examining information from various reports to determine whether or not to follow through with a formal investigation. In the meantime, humanitarian aid in the form of food, money, doctors, medical supplies, and diplomacy are necessary and temporary fixes to prevent any further tragedies. Venezuela's neighboring countries will soon be responsible for upholding the U.N. doctrine, "Responsibility to Protect," under which they must commit themselves to protecting Venezuelan citizens from their own government. Under R2P, serious actions must be taken by the international community in recognizing the crimes against humanity and major issues happening in Venezuela.

In conclusion, the international community is not taking sufficient steps in resolving the crisis. The Trump administration has condemned the Maduro government and imposed sanctions on leading officials, but it still must take a leading stance on dealing with a hemispheric refugee crisis. Rather, American conservatives are utilizing Venezuela's plight as rhetoric about the dangers of socialism, "a parable they hope will scare U.S. voters away from left-wing Democrats in the upcoming midterm elections" (Tharoor 2018). The New York Times has identified the crisis as "the largest migration in the history of Latin America since the slave trade" (Castaneda 2018), which is a fact so alarming that the U.N. should seek to recognize it as an official refugee crisis 
immediately. This would hopefully prompt donations and aid on a large-scale basis and would provide some support to the Venezuelan people. Ultimately, the government of Venezuela must be held accountable for the war crimes they have committed throughout recent years. If the U.S. were to impose stronger economic sanctions, provide military presence, and remove Maduro from power, it would then be indisputably responsible for what happens next. External intervention has been dismissed in recent months yet remains a possibility for a future in which Maduro attempts to become the authoritarian dictator of Venezuela. If Nicolas Maduro is forcibly removed from the presidential office of Venezuela, the question of who would replace him and what their politics are remains an interesting one. 


\section{REFERENCES}

Al-Jazeera. 2018. "WHO: Venezuela malaria cases jump by 69 percent.” Aljazeera, April 25, 2018. https://www.aljazeera.com/news/2018/04/venezuela-malaria-cases-jump-69percent-1804241 72239443.html

Berlinger, Joshua and Gafas, Mallory. 2018. "Venezuela: Suspect in Maduro assassination plot dies in mysterious fall from window." CNN, October 10, 2018.

https://www.cnn.com/2018/10/09/americas/venezuela-assassination-plot-intl/index.html

Carrillo, Pedro E. 2016. "How today's crisis in Venezuela was created by Hugo

Chavez's 'revolutionary' plan.” The Conversation, July 5, 2016.

https://theconversation.com/how-todays-crisis-in-venezuela-was-created-by-hugochavezs-re volutionary-plan-61474

Castaneda, Jorge G. 2018. "Venezuela Is a Disaster. Time for a Coup?” New York

Times, September 26, 2018. https://www.nytimes.com/2018/09/26/opinion/madurovenezuela-crisis.html

Ellis, Sam. 2017. The collapse of Venezuela, explained. Vox Media, Video. From Vox, World. YouTube, 7:32. https://www.vox.com/videos/2017/8/29/16201552/collapse-maduro-venezuelaexplained

Faiola, Anthony and Krygier, Rachelle. 2017. "As Venezuela disintegrates, Maduro consolidates power.” The Washington Post, December 9, 2017.

https://www.washingtonpost.com/world/the americas/as-venezuela-disintegrates-maduroconsolidates-power/2017/12/08/f9e5b366-dc27-11e7-a241-

0848315642d0_story.html?noredire ct=on\&utm_term=.4b3368df1871

International Criminal Court. 2018. "Statement of the Prosecutor of the International Criminal Court, Mrs. Fatou Bensouda, on the referral by a group of six States Parties regarding the situation in Venezuela." From the Office of the Prosecutor, September 27, 2018. https://www.icc-

cpi.int/Pages/item.aspx?name=180927-otp-stat-venezuela

Laya, Patricia and Rosati, Andrew. 2018. "Venezuela's 2018 Inflation to Hit 1.37 Million Percent, IMF Says.” Bloomberg, October 8, 2018. https://www.bloomberg.com/news/articles/2018-1009/venezuela-s-2018-inflation-to-hit-1-3 7-million-percent-imf-says

Lohman, Diederik. 2015. "Venezuela's Health Care Crisis.” Human Rights Watch, April 29, 2015. https://www.hrw.org/news/2015/04/29/venezuelas-health-care-crisis

Marillier, Lou and Squires, Daisy. 2018. "Lacking Birth Control Options, Desperate Venezuelan Women Turn to Sterilization and Illegal Abortion." The Intercept, June 10, 2018. https://theintercept.com/2018/06/10/venezuela-crisis-sterilization-women-abortion/

Nugent, Ciara. 2018. "How Hunger Fuels Crime and Violence in Venezuela.” Time, October 23, 2018. 
http://time.com/longform/hunger-crime-violence-venezuela/

O’Neil, Shannon K. 2018. “A U.S. Military Intervention in Venezuela Would Be a Disaster.” Council on Foreign Relations, September 18, 2018. https://www.cfr.org/article/us-military-interventionvenezuela-would-be-disaster

Raphelson, Samantha. 2018. "Venezuela's Health Care System Ready To Collapse Amid Economic Crisis.” National Public Radio, February 1, 2018.

https://www.npr.org/2018/02/01/582469305/venezuelas-health-care-system-ready-to-collaps e-amid$\underline{\text { economic-crisis }}$

Scharifker, Diego. 2018. "Accounts of brutal torture further isolate Venezuela. But we need justice." The Washington Post, June 6, 2018. https://www.washingtonpost.com/news/globalopinions/wp/2018/06/06/accounts-of-brutal-to rture-further-isolate-venezuela-but-we-needjustice/?utm_term=.db2d3660df 22

Shugerman, Emily. 2018. "Venezuela rated least safe country in the world for second year in a row." Independent, June 7, 2018. https://www.independent.co.uk/news/world/americas/most-dangerouscountry-venezuela-saf e-south-america-gallup-a8388736.html

Tharoor, Ishaan. 2018. "Venezuela's refugee exodus is the biggest crisis in the hemisphere." The Washington Post, August 23, 2018. https://www.washingtonpost.com/world/2018/08/23/venezuelasrefugee-exodus-is-biggest-cr isis-hemisphere/?utm_term $=.9 \mathrm{a} 10687 \mathrm{adb} 49$

Ulmer, Alexandra. 2018. "Cash-strapped Venezuela sets new wages for oil workers as protests simmer." Reuters, October 10, 2018. https://www.reuters.com/article/us-venezuela-oil/cash-strappedvenezuela-sets-new-wages-fo r-oil-workers-as-protests-simmer-idUSKCN1MK2IX

Venezuela Investigative Unit. 2018. "Drug Trafficking Within the Venezuelan Regime: The 'Cartel of the Suns." InSight Crime, May 17, 2018. https://www.insightcrime.org/investigations/drug-traffickingvenezuelan-regime-cartel-of-the-sun/

Watts, Jonathan. 2016. "'Like doctors in a war': inside Venezuela's healthcare crisis.” The Guardian, October 19, 2016. https://www.theguardian.com/world/2016/oct/19/venezuela-crisis-hospitalsshortages-barcelona-caracas

Watts, Jonathan. 2016. "Venezuela on the brink: a journey through a country in crisis." The Guardian, October 11, 2016. https://www.theguardian.com/world/2016/oct/11/venezuela-on-the-brink-ajourney-through- a-country-in-crisis

World Bank. 2015. “World Bank Forecasts Global Poverty to Fall Below 10\% for First Time; Major Hurdles Remain in Goal to End Poverty by 2030." The World Bank, October 4, 2015. http://www.worldbank.org/en/news/press-release/2015/10/04/world-bank-forecasts-global-po vertyto-fall-below-10-for-first-time-major-hurdles-remain-in-goal-to-end-poverty-by-2030

Wyss, Jim. 2017. "In Venezuela, people fear the night, and the cops are not much help, study shows." Miami Herald, August 3, 2017. https://www.miamiherald.com/news/nationworld/world/americas/venezuela/article16505750 2.html 